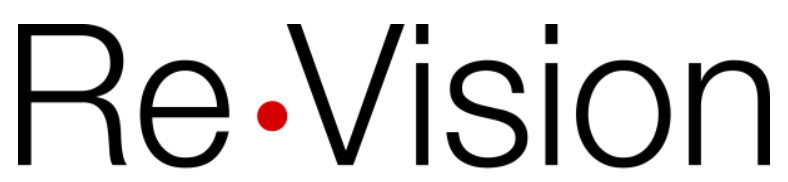

UNIVERSITY

\title{
Re/Turning the Gaze: Unsettling Settler Logics Through Multimedia Storytelling
}

Carla Rice

University of Guelph

Susan D. Dion

York University

Hannah Fowlie

University of Guelph

Ingrid Mündel

University of Guelph

This is an Accepted Manuscript of an article published by Taylor \& Francis in FEMINIST MEDIA STUDIES on January 6, 2020, available online: https://www.tandfonline.com/doi/full/10.1080/14680777.2019.1707256.

\section{Recommended citation:}

Rice, C., Dion, S.D., Fowlie, H., \& Mündel, I. (2020). Re/turning the Gaze: Unsettling settler logics

through multimedia storytelling. Feminist Media Studies. https://doi.org/10.1080/14680777.2019.1707256 


\section{Re/Turning the Gaze: Unsettling Settler Logics Through Multimedia Storytelling}

Carla Rice, Susan D. Dion, Hannah Fowlie and Ingrid Mündel

\section{Abstract}

Drawing on three decolonizing feminist arts-based research projects, we discuss possibilities for making multimedia stories that counter, respond to, and re/turn the heteropatriarchal settler colonial gaze. All three projects use a participatory videomaking method that involves misrepresented communities producing short films to advance social justice. We explore how the creation of narrative videos by Indigenous researchers, educators, students, and artists, and allies offer multiple avenues for returning the interconnected gaze of heteropatriarchy and colonialism, creating a feminist decolonizing aesthetic—an embedded and embodied aesthetic—that consciously weaves together process and form. We consider moments of re/turning, refusing, and reckoning with the colonizing masculinist gaze through analyzing the videos organized along three themes: the catalyzing effects of educational experiences, both destructive and empowering; the complex decolonizing affects of love; and the pervasive and debilitating effects of everyday gendered racism in/beyond school. We offer reflective analysis by drawing on feminist decolonializing theories on the power in looking and in interrogating heteropatriarchal colonial discourse. Each of the stories that we analyze re/turns the interconnected gaze of heteropatriarchy/colonialism in ways that extend responsibility for colonialism, for misogyny, for racism, for gender/sexual normativity, to the viewers of these films-to all of us. 


\section{Keywords}

heteropatriarchal colonial gaze; multimedia storytelling; settler colonialism; decolonizing feminism; gender complementarity; decolonial love, decolonizing intersectionality

\section{Introduction}

To watch the stories presented in our paper, go to https://vimeo.com/album/4877492; password "unsettling". Please note: these videos are intended for educational purposes only.

Drawing on three recent Indigenous and decolonizing feminist arts-based research projects, in this paper we discuss processes of decolonization and possibilities for making and telling multimedia stories (short films) that counter, respond to, and re/turn the heteropatriarchal settler colonial gaze. All three projects featured use a creative research method that involves misrepresented communities producing short narrative films to advance social well-being and justice. We explore how the creation of first-person videos by Indigenous researchers, community mobilizers, educators, students, and artists, and non-Indigenous allies on Turtle Island (North America) offer multiple avenues for re-turning the interconnected gaze of heteropatriarchy and colonialism, contributing to a feminist decolonizing and indigenizing aesthetic-an embedded and embodied aesthetic_-that consciously weaves together process and form. We understand feminist decolonizing and Indigenous frameworks to be interrelated but also distinct modes of thought and action: while Indigenous feminist theory/praxis places emphasis on uncovering, contesting, and thinking beyond heteropatriarchal structures of colonial oppression (Suzack, Huhndorf, Perreault, and Barman 2010), feminist decolonizing frameworks seek to interrogate what is required to 
decolonize settler symbolic and social systems (Arvin, Tuck, and Morrill 2013). Juan Salazar and Amalia Cordova discuss the interconnectedness of process and product in Indigenous media production/ self-representation in ways that resonate with our analysis—especially in their emphasis on Indigenous filmmakers' use of socially embedded, collectivist media practices to generate stories that seek to "shape counter discourses and engender alternative public spheres" $(2008,40)$. In a similar vein, Kerstin Knopf argues that the "process of visual and sonic self-representation" of Indigenous people returns the neo/colonial gaze as the videomakers use the "formerly colonialist means of production [to] [...] look critically at colonialist images and discourses" $(2010,93)$.

In the analysis of our video-work, we heed the call issued by Native feminist scholars Maile Arvin (Kanaka Maoli), Eve Tuck (Unangax) and Angie Morrill (Klamath), who assert that "attending to the links between heteropatriarchy and settler colonialism is intellectually and politically imperative for all peoples living within settler colonial contexts." $(2013,8)$ As they and others have shown, colonial processes are deeply intertwined with heteropatriarchal ones; through state mechanisms (in the Canadian context) such as the Indian Act and residential schooling, settlers imposed heteropatriarchal structures-the nuclear family, the heterosexual matrix, the masculinist political economy—onto Indigenous families and nations (Anderson, 2016). If we accept that heteropatriarchy is integral to settler colonialization, it then follows that we must dismantle gender/sexual regimes in order to achieve Indigenous sovereignty and self-determination. Maile et. al. further argue that Indigenous feminism has been at the centre of feminist thought all along but has been made invisible "by the gendered 
logics of settler colonialism for over 500 years" (14). Acknowledging this erasure, a decolonial feminist approach works to uncover the complex, multiple effects of colonialism on Indigenous gendered and sexual identities (via the disruption of nonbinary concepts of gender/ sexuality and systems of gender complementarity), kin and community (through forced assimilation, cultural genocide, intergenerational trauma), and belonging (through theft of lands and languages). A feminist decolonial approach further interrogates how, at their core, colonial processes that have forcibly removed Indigenous peoples from land as an integral site of self and nation-building represent settler efforts to eradicate Indigeneity. The video-makers' centering of the impacts of, and their resistances to, colonial violence levelled against their land-based ways of being, knowing, and living necessitate that we rethink intersectionality through a spatial, embedded lens. This decolonized revisioning, we argue, can account for settler colonialism as a system distinct from and underpinning the structures/relationships that are typically considered in intersectionality research. By opening up possibilities for enunciating Indigenous voices, the video-making workshops and the videos produced in these spaces provide entry points for developing just such a decolonized intersectionality.

The films we analyze are derived, in part, from nlshnabek de'bwe wln//telling our truths (PI Dr. Susan Dion), a research grant on which the first three authors have worked that focused on teaching and learning about Indigenous experiences of schooling through decolonizing filmmaking practices. Our second multi-media engagement with telling stories focuses on what it is to be Inuit today and what kinds of futures are (or aren't) being imagined for the Inuit within the cultural imaginary of 
Canada. The project, in part, takes inspiration from the Arnait Inuit Indigenous women's filmmaking collective which responds to the absence of female voices in Indigenous Arctic filmmaking through bringing together women-dominant technical staff to tell stories that center Inuit women (MacKenzie and Westerståhl Stenport 2016). This initiative is part of a broader research project, Mobilizing Inuit Cultural Heritage (PI Dr. Anna Hudson), which conducts collaborative research on the contribution of Inuit visual culture, art, and performance to Inuit language preservation, social well-being, and cultural identity. The final project, Through Thick \& Thin: Body Image and Body Management among Queer Women (PI Dr. Jen Rinaldi) brought together diverselylocated queer women and trans researcher-storytellers to story their experiences of queerness, fatness, and eating through digital media (Lind, Kotow, Rice, Rinaldi, LaMarre, Friedman and Tidgwell 2017; Rinaldi, Rice, LaMarre, McPhail, and Harrison, 2017; Rinaldi, Rice, LaMarre, Jiménez, Harrison, Friedman, McPhail, Robinson, and Tidgwell 2016). What these three projects have in common is that they offer spaces from which storytellers assert feminist, queer, and decolonizing worldviews and perspectives, and construct an alternative past, present, and future by and with Indigenous peoples.

Our work has been conducted against a history of colonial heteropatriarchal ways of seeing that date back to the $19^{\text {th }}$ century when euro-western male scientists first began putting new visual technologies (photography, film) to work in documenting encounters between colonizers and colonized. The scientific spectacle that characterizes much of this record has been described as the "colonial gaze," a "visual pathology" that constructs colonized bodies as "entomological or zoological specimens" 
(Amad 2013, 49). Feminist theorists have shown how early scientific and later classic film borrowed from gendered conventions in euro-western art to reproduce a parallel "male gaze", which constructs the meanings of gender and sexual difference by positioning men as active bearers and women as passive recipients of the look within a heterosexual matrix of desire (Mulvey 1975). According to E. Ann Kaplan $(1997,28)$, while imperial and male gazes "collude and conflict" in western film, ultimately, they are impossible to disentangle as both privilege a white heteropatriarchal perspective and interpolate spectators into a hegemonic viewing position in which that worldview is produced as normative. Though many early anticolonial and feminist scholars analyzed colonial and male gazes as unidirectional, emphasizing the power of colonizer and heteropatriarchal image-makers to look without being looked at, recent scholarship complicates this visual narrative, analyzing how Indigenous peoples, women and queer subjects "return the gaze." For Paula Amad $(2013,52)$, moments of "visual reposte" or "specular antagonism" in colonial films that otherwise uphold western superiority are marked by Indigenous self-assertion through looking back (staring, turning away) in ways that refuse the dominance of the camera and the person behind it, and that affect and implicate the audience as complicit in the ongoing perpetuation of colonialism. Belief in the radical capacities of re/turning the gaze that emerged from postcolonial and feminist film studies has since spread to artists engaged in "filming their way out of formerly colonized [and gendered/ sexually othered] subject positions" $(2013,64)$, taking their video-making into new aesthetic terrain.

Mindful of the ethics and politics surrounding our differing positionalities as Indigenous and non-Indigenous scholars, we move between Indigenous and decolonial 
feminist frameworks in our analysis while we hold shared commitments to reconciliation (which involves symbolic/structural transformation and land repatriation). Our analysis and discussion of methodology that follows brings together feminist, Indigenous and decolonizing approaches, emphasizes the interconnectedness of process and product, and foregrounds embodied and embedded elements that characterize the filmmakers' justice-seeking voices and perspectives. We consider moments of re/turning, refusing, reckoning with the gaze through analyzing six videos produced through our research organized along three themes: the catalyzing effects of educational experiences, both destructive and empowering (and sometimes both); the complex decolonizing affects of love; and the pervasive and debilitating effects of everyday gendered racism in/ beyond school. We offer reflective analysis on the stories featured from a feminist decolonizing lens that surfaces interconnected gendered and colonial looking relations. We draw on Kaplan's theories on the power in looking and her interrogation of masculinist colonial discourse. For Kaplan, women filmmakers who "produc[e] new ways of seeing, new readings of the past, as well as new images of inter-racial looking relations" participate in the "healing [of] imperialized eyes" $(2012,219)$. Each of the stories that we analyze re/turns the interconnected gaze of heteropatriarchy and colonialism in ways that extend responsibility for systemic injustice, for hetero/sexism, for misogyny, for racism, for gender normativity to the viewers of these films—to all of us.

\section{Methodology: Talking Back, Learning From}

The Re•Vision Centre for Art and Social Justice (hereafter Re•Vision) is an arts methodology research hub at University of Guelph in Ontario, Canada that investigates the power of the arts to open up conversations about systemic (rather than 
individualized) injustices in healthcare, education, and the arts sectors (for a detailed analytic overview see Rice and Mündel 2018). Over the past six years, we have built an archive of over 800 videos from a range of projects—including the Indigenous projects featured here. Working in community with a diversity of body-minds Re $\bullet$ Vision understands the necessity of accessible arts and scholarship. As a result, we have developed the accessibility practice of describing our films that recognizes the accessibility requirements of blind and low vision readers as well as of non-visual learners more generally (Rice and Mündel 2019; Rice, Chandler, Liddiard, Rinaldi, and Harrison 2018). This work exemplifies Re•Vision's interest in the appropriation and creative retailoring of technology for feminist decolonizing purposes. Like other decolonizing arts-based research, $R e \cdot V i s i o n$ focuses on storytelling as a research creation and knowledge mobilization method. What makes our processes unique are the artistic practices that we have developed in partnership with First Nations, Métis and Inuit researchers, artists, and community leaders and non-Indigenous allies, which we undertake to open dialogue with an aim to build decolonized intersectional and intersectoral alliances (Rice and Mündel 2018). Rather than conducting research for Indigenous communities, we support research with and by Indigenous and nonIndigenous researchers and artists working together to decolonize representations, knowledge and systems.

Across these projects, we worked to create spaces in which interchange about Indigenous-settler relations became possible, by bringing together Indigenous community members and allies located in systems (such as Canada's public-school and healthcare systems) implicated in Indigenous people's misrepresentation/ alienation 
(Dion 2009; Dion, Rice and Johnson 2010; Rice and Mündel 2018). We adapted our methods accordingly, mounting 3 to 4 day-long workshops in which storytellers cocreated multimedia stories: $1-5$ minute-long videos pairing audio recordings of participants' voices with photographs, video, music, dance, artwork, and more. During the nlshnabek de'bwe wIn//telling our truths project, storytellers benefitted from the guidance of Knowledge Keeper, Ed Sackaney (Anishinaabe) who reminded us that stories are sacred; and the PI Dr. Susan Dion (Lenape/Potawatomi) shared that stories are told in the moment with intention and that it is the listeners' responsibility to pay close attention. In the Inuit Futures project, Inuit artist Ruben Komanjapik opened the storytelling circle-where stories are shared orally before their digital incarnation—with an Inuit drum dance. We recognize that embedded as we are in hegemonic narratives that re/construct certain perspectives (white, settler, male, straight) as normative, "telling our stories" was not enough (Rice, LaMarre, Changfoot and Douglas 2018, 15; Rice, Chandler, Harrison, Ferrari, and Liddiard 2015). To push against dominant framings, we created new curricula for each project that highlighted problems with existing representations, showed how Indigenous artist-activists have responded to these, and discussed how video-makers might use their stories to intervene in dominant storylines (Rice, Chandler, Harrison, Ferrari, \& Liddiard, 2015). At the same time, we were clear that the stories told are the video-makers' own-that they control the content. Susan Dion led the storytelling circles with care, emphasizing the embeddedness of participant stories in relationship and community before moving to the technological realm. Our research team hired Indigenous artists to co-lead the workshops in order to 
(temporarily) shift colonial power dynamics that operate in storytellers' lives (Rice and Mündel 2018).

Indigenous scholars have shown how theoretical frameworks rooted in colonial worldviews frequently distort the meanings encoded in Indigenous stories. Jo-ann Archibald (Stó:lo) argues that to avoid participating in this act of what Leanne Betasamosake Simpson (Michi Saagiig Nishnaabeg) sardonically/seriously calls "postcolonial colonization," $(2011,20)$ researchers "must read and hear the voices of First Nations/Indigenous peoples and find the theories embedded in their stories" (Archibald, 2008, 16). To push against reproducing colonial dynamics in our interpretive process, our team of Indigenous and non-Indigenous researchers engaged in a triple hermeneutic: following Indigenous research protocols, we watched and discussed the videos with a group of "insider witnesses"—urban Indigenous artists, educators, community members, students and parents, including many of the participant videomakers-to hear their/our affective reactions to and thoughts on the meanings embedded in the videos; we then discussed our interpretations, both with video-makers and later among ourselves as researchers deeply engaged in co-producing the videos with the makers; and finally we showed curated selections of the videos in professional development sessions delivered to non-Indigenous educators and health care practitioners as a way of opening dialogue about what is required to decolonize systems. For some of these sessions, we gathered surveys and conducted follow-up interviews with self-selecting participants focused on the impacts of the stories on their practice (which we present and analyze in another article). Rather than hide our affective responses to the stories shared, we tried to be conscious of our embodied 
reactions-paying attention to the flows of sensation and affect as clues to learning and meaning making.

In the paper, we aim to ply open the western gaze and with it, western ways of fixing indigenous bodies, identities and lives as "objects" that can be known. Even as we work in visually-oriented video storytelling genres, we reject any western ontology that takes an object-oriented view to reality, challenging the empiricist idea that "seeing is believing" and empiricism's orientation to the material world as relatively stable, discoverable (or in the case of the camera, capturable) and knowable. Instead we endorse indigenous ontologies that highlight the fluidity and processual nature of reality, orienting to organic and inorganic things as continuously moving and shifting, and in ongoing dialogue with Indigenous ways of knowing (Tallbear 2015). In-keeping with this ontology, we understand our analyses and the storytellers' own interpretations of their lives as provisional truths that offer up critically important visions of and insights into the situated moments in and about which they were crafted. As we have elsewhere written, "we recognize that all accounts, whether written, told, or imag(in)ed, are partial truths and that the truths of aggrieved groups must be proliferated if we hope to create a more just society." (Rice and Mündel 2018, 219)

\section{Re/Turning the Gaze}

\section{Catalyzing Effects of Educational Experiences, Both Destructive and Empowering}

In the first set of films we analyze, Indigenous youth explore the catalyzing effects of educational experiences, both destructive and empowering (and sometimes both). Their stories return the gaze by teaching us what it means to be Indigenous and to be in school through the intimacies of family history, community affiliations, 
relationship to land and resurgence. Coming to know their indigeneity amidst a barrage of representations, storytellers draw a complex and layered picture, turning our gaze to immense diversity—in gender, sexuality, race, nation, and mixed identity—present in urban Indigenous populations (Dion, 2009). The type of school environment (socially progressive/ conservative) and proximity to that environment (currently attending/ recollecting past experiences) shapes how tellers weave themes of sexuality and gender into their stories. Those who face particular rhetorical challenges of "telling" intersectional stories do so, in large part, as a result of the policing of bodies in school contexts. Still, family and community histories occupy a significant place in their understanding of themselves, and all have some understanding of how gendered colonialism impacts their lives. Speaking back to settler framings, tellers relate their knowledge of the complexities of urban Indigeneity (entangled with other identifications) in contemporary times. They do not simply wait for change; they actively engage in searching and in representing that search. Through creative expression, they also contribute to the project of decolonizing gender, the self and creating decolonized spaces in schools and other colonial institutions.

Ryan Neepin's My Story is captivatingly "double-voiced," where his perspective as Cree with a loving connection to his family, and especially his Nana, is consistently undermined and overwritten by his experiences in the classroom (https://vimeo.com/album/4877492; password "unsettling"). Neepin creates "doubleimages" throughout his video, superimposing photographs of his Nana, himself and his family on opaque backdrops. He shows a scene of urban nature and splits the screen to a brick school building with empty, haunted hallways; he tells us that during his First 
Peoples and Pioneers unit in school he wondered aloud about Indians and was told by his teacher that settlers brought diseases that "Natives couldn't handle so they died." Neepin's ability to position himself as Indigenous, as present, despite the persistent messages he gets to the contrary defies settler logics. By placing his relationship to his Nana at the centre of his story and emphasizing how she holds and passes on culture, identity and respect for the land, Neepin resists colonialism's heteropatriarchal rationalities. His video shows how Indigenous people carry stories of survival from their/our parents, grandparents, aunties and uncles and summon these teachings when confronted with settler arrogance and stereotypes. Whether Indigenous peoples live on reserves or in urban centers, their/our histories include being dispossessed of traditional territories, surviving imposed patriarchal-colonial systems of government, education, and law, and recovering from attempts to eradicate Indigenous languages, cultural practices and governance systems. We bear the marks of colonialism and live with its legacies.

Knowing that these videos would be shown to educators, Neepin intentionally invites viewers to see, hear, and feel how Indigenous students experience teachers' words. He uses close ups to bring viewers eye-to-eye with his father as he mimics the teacher's voice: "Your father has a job; he wouldn't like you telling people you're Indian." While the teacher appeals to patriarchal authority - the law of the father-to determine Neepin's status/identity, Neepin turns to another source, to an Indigenous system of authority embodied in his Nana. By invoking Nana's power and presence, Neepin reinscribes what settler-scholar Leah Sneider refers to as gender complementarity, the "set of values that have held strong and continue to guide and define Indigenous 
cultures in the face of ongoing colonization and neo-colonization" $(2012,74)$. According to Kim Anderson (2016) (Métis), colonizers interpreted gender complementarity—which assigned complementary leadership roles to Indigenous women and men and recognized non-binary sexual and gender expression of two-spirit peoples-as a threat to heteropatriarchal rule and so made eliminating these systems a central tenet of the colonial order. Repeating his teachers' story about the Natives who care so little for property they throw garbage out their front-door, Neepin, his words filled with love overlayered with sarcastic humour and strategic confusion, reflects, "that doesn't sound like my Nana. Nana never throws anything out." When we show this story to Indigenous audiences, we witness a moment of recognition that evokes laughter; and while nonIndigenous audiences do not audibly react, we read their body language and expressions (shifting in chairs; puzzled looks) as discomfort. The laughter only seems to increase the power of the re-turned gaze, drawing attention as it does for Indigenous viewers to the authority of Indigenous grandmothers and for non-Indigenous ones, to discourse of lazy dirty Indians (Francis 2012) hauntingly familiar in the stories settlers know and tell. Neepin refuses the teachers' attempt to invoke male authority as a silencing tool, relying instead on the authority of his Nana to affirm Indigenous women's presence and place as in positions of power as knowledge makers/keepers.

Emma Allan's Crying Stall offers another powerful take on the turbulent pathways through education for Indigenous two-spirit students and another complicating perspective on how to engage and return the heteropatriarchal colonial gaze (https://vimeo.com/album/4877492; password "unsettling"). Allan runs, barefoot, through a maze of school hallways, trying to open locked doors, trying to escape. They 
intertwine images of school classrooms and everyday scholastic objects such as pens (that turn into weapons) with historical images of Indigenous peoples framed by the colonial camera and captured in residential schools. All the while, Allan repeats the phrase, "Will I take it?" They refuse, saying, "No," and staring into the camera before they run through hallways again, finally resting at the door to the "All Gender" bathroom. Their story shows how curriculum content can address students' need for knowledge of Indigenous history but also inflict pain especially when lessons ignore the trauma Indigenous students feel when hearing detailed accounts of oppression experienced by not only distant ancestors but by close kin. Additionally, stories of the systemic, ongoing nature of colonialism intersecting with other oppressions occurring at multiple sites in school can turn a history lesson into a traumatizing event. This requires that we reckon with the ways that colonial processes are gendered, sexualized and importantly, embodied. The kind of intersectional nuance offered by Allan's story doesn't give easy answers, and points to colonialism's entanglement in hetero-patriarchal and other forms of oppression. Allan finds space to recoup their Indigenous queer/two spiritedness in the school's gender inclusive bathroom, which, borrowing from Harry Potter, they dub their "crying stall," thus, turning Rowling's parody of teenage girl angst into a sanctuary for Indigenous two-spirit student recuperation.

Though often positioned as "at risk"-an assessment imposed on and situated within the failings of individual students_-Indigenous students like Allan disrupt that narrative by shining light on their capacities to survive and resist. Allan evokes a visceral experience of panic as the camera spans a school landscape, zooming in on images presented to them in a matter-of-fact way. Allan brings viewers on a panic-filled 
tour of what school can feel like and audiences experience a sense of being trapped with them - wanting Allan to arrive at a place of safety. Attending to the distance between viewers and Indigenous students in schools, Allan manages to "rupture the supposed cinematic and temporal distance between themselves and the audience, disrupting their viewers' 'voyeuristic pleasure'” (Romero 2010, 54). Their story invokes implication and teaches us that any politics of sexuality and gender that are not explicitly decolonizing will continue to erase two spirited/queer Indigenous people's existence.

Both Neepin and Allan bring queer/feminist and decolonial aesthetics into dialogue in a way that unsettles both. Their orientation to place-whether to the reserve, the home or the crying stall-follows that of other Indigenous filmmakers, who as Salazar and Cordova $(2008,40)$ observe, construct an "embedded aesthetics" that reflects the social (and, we add, relational and spiritual) embeddedness of Indigenous cultures and video-making practices. Using close-ups of their own and their families' faces, the films also "reflect an [embodied] intimacy with its subjects that differs from the detached" (Romero 2010,54) generalized approach to representing Indigenous people as objects of study. In this the filmmakers enact what Kaplan calls an "embodied aesthetics" that follows other feminist-queer filmmakers in creating "ways of bodily knowing" $(2012,17)$. An embodied aesthetics revalues corporeal, subjective, and emotionally-charged expressions in ways that illuminate difference, asymmetrical power relations, and alternative versions/visions of the past, present, and future.

\section{Complex Decolonizing Affects of Love}

At its core, decolonial love moves around heteropatriarchal structures of colonial oppression by recuperating traditions of gender complementarity (power sharing 
between men and women) and gender fluidity (non-binary conceptualizations of gender and sexuality) once commonplace among many Indigenous peoples (Simpson 2017). Decolonial love wrestles with gender injustices wrought by colonialism, such as gender and sexual violence (Olsen 2017) and rejects the framing of certain heteropatriarchal values and practices as 'traditional' (St. Denis 2013). Jill Carter (Anishnawbe), Karyn Recollet (Cree), and Dylan Robinson (Stó:lo) (2017) describe a decolonization model that provides a helpful way for thinking our ways around colonial wounding and toward decolonial love-love that actively works to challenge the ongoing effects of colonialism. Carter refers to the five stages, developed by Hawaiian scholar, Poka Laenui, grief being the unavoidable first, that we need to push through to find our way to recovery/rediscovery, dreaming, commitment, and finally to action. This framing requires that Indigenous people and settlers alike take ownership of our stories, walk in solidarity on a separate road towards decolonization, and for settlers especially, to turn the gaze on ourselves, and direct our needs, wants and desires toward the creation of reciprocal relationship. And then perhaps we may open a space for the beginnings of a decolonizing kind of love.

In My Mi'kmaw Body, Margaret Robinson offers a lovingly subversive account of the "Aboriginal thrifty genotype" (https://vimeo.com/album/4877492; password "unsettling"). She zooms in on a voluptuous photo of a basket of eggs as she speaks of her father, whose childhood was a hungry one, and his belief in "the power of eggs." This film opens on the strong statement "I have a proud survivor's body." As Robinson shows images of her people in traditional clothing, she goes on to attribute the survival of her Mi'kmaw ancestors to their possible evolutionary capacity to store fat. Her story 
subverts the dominant meanings of fatness as disease or health risk (especially among Indigenous peoples), into a defiant mode of embodiment for surviving colonial history and for signifying ancestral connection and kinship (Rice, Pendleton Jiménez, Harrison, Robinson, Rinaldi, LaMarre and Andrew, forthcoming). She visually and metaphorically connects her favourite food, dome-shaped "bologna hats" (bologna slices frying in a cast-iron pan), to cherished cultural objects, the cone-shaped hats worn by Mi'kmaw women, tying both "hats" to inter-corporeal and inter-generational intimacies. While Robinson figures food as survival in the face of colonial violence, food is never simply about sustenance. Food is marked as resistance to colonialism and emerges as a vital force in opening to the possibility of decolonial love. That is, at the same time that Robinson writes colonial trauma in terms of access and relationships to food ("As colonists forced the Mi'kmaw from our territories, my people suffered from malnutrition") she also reinscribes it as the connecting force in her relationship to her father: "As a kid my dad didn't get enough to eat. So, his love takes the form of food." In Robinson's decolonial love story, food is love and love is food-sustaining and nurturing across generations: "My genes rejoice. And store the fat."

Robinson's decolonial love story also involves an explicit reclamation of her twospirit identity, and in so doing draws attention to the centrality of heteropatriarchal relations to the settler colonial order and the need to dismantle gender/ sexual regimes to achieve a feminist, queered vision decolonialization and Indigenous sovereignty. In her film, Robinson invokes the "Femme Fatale" trope, a classic figure in cinema history, but also a complicated one that is often upheld by feminist scholars as marking the beginning of more complex representations of women, desire/desirability, and sexual 
agency in film. As settler theorists Helen Hanson and Catherine O'Rawe suggest, "it is the ambiguity of the femme fatale that affords the figure such an enduring currency for feminist approaches to film, as well as constituting a challenge to those very approaches" (2010, 225). Robinson contrasts her embodied experience (being "the shortest in class, infantilized, uncoordinated, chosen last in sports, shaped like my people...") with whom she imagines herself to be: "In my imagination, I'm Lauren Bacall in a sports car: tall, sleek, and dangerous." As her narrative unfolds, Robinson speaks back to her experiences of feeling infantilized and unsettled in her body both by reclaiming food as relationship and history, and by reclaiming the gaze as an Indigenous woman and a Femme Fatale. Her film ends on an image of herself wearing "the pointy hat of my people" that she has sewn herself, proudly asserting "it makes me visible, feminine, retro. A M'ikmaw Femme Fatale, like I can grab my culture, pull it through time and into my life. On my round eggy head, it sits. Proud. Like a bologna hat."

Robinson's story powerfully decolonizes love relations in its figuring of food as love in her bond with her father and with her M'ikmaw ancestors more broadly, and in its recasting of the Femme Fatale as herself, a brainy, short, bologna-loving M'ikmaw woman. This kind of decolonizing approach to gender, desire/desirability and love relations takes on a very different resonance in settler/ colonizer-Indigenous relationships (intimate and otherwise). Dylan Robinson points to a different kind of consumption marking settler/ colonizer-Indigenous relationships when he speaks about the Stó:lo word for Settler, "Xwelitem." The literal translation of "Xwelitem" is "starving person" (Carter, Recollet, and Robinson 2017, 210). Robinson discusses this all- 
consuming settler hunger as nothing new, the hunger for land, water, air, and bodies having been present since first contact. While Margaret Robinson's consumption of food becomes about sustaining life and love in the face of colonial violence, white settler consumption, according to Karyn Recollet continues on in "the consumption of ideas, words, and processes [...] becoming intermeshed with the desire and hunger for Indigenous methodologies" $(2017,212)$. Recognizing how a colonial research apparatus has monopolized knowledge about Indigenous peoples and marginalized Indigenous knowledge systems, we see our methodology as both indigenizing and decolonizingas informed by Indigenous epistemologies and ontologies, and as decolonizing in its aim of turning a critical gaze on western worldviews and power structures they uphold (Kovach 2009). Yet following from Recollet, how do we hold space for one another within and apart from ravenous settler colonialism? How can desire for Indigenous bodies, ideas, and relationships, the Xwelitem's insatiable hunger for otherness, be contested and replaced by walking with but apart in ways that enact "radical relationalities" (213)?

Exploring another dimension of "radical relationalities," in Carla Rice's story, Over Exposed, she telescopes viewers into a confrontation with settler colonization while she films a drive through the backroads of her native Cape Breton Island (located off the coast of Nova Scotia) (https://vimeo.com/album/4877492; password "unsettling"). The camera microphone records her speaking to an unnamed intimate (Gaelic-accented) other, its lens witness to the ubiquitous road signs that reveal how her Scottish ancestors re-named the terrain in their own image: Gaelic. The Scottish Gaelic placenames that punctuate the landscape are only a tiny remnant of settler efforts to 
indigenize themselves, which required the forced removal of the Mi'kmaw from their territories onto apartheid-like reserves. Travelling with her Indigenous queer spouse back to this "home," Rice's living history is brought into stark relief, forcing her to confront Mi'kmaw peoples' continued dispossession from their land/language/resources, and urging her to see the implicatedness of her kin in ongoing silences and neocolonial processes. As she, her mother, and her partner walk through the halls of her childhood convent school, the camera seizes upon the image etched in the glass doors of Indigenous children standing around a white settler Nun with the inscription "Canada's First Teacher." Through this confrontation and against the dominant narrative of reconciliation — which is often cast by settlers as one of friendship and love-she comes to understand that love is not all that is needed for reconciliation; the dominant narrative typically involves the absorption of Indigenous into settler logics (which value individualism, privatization and ownership) and intimacies (rooted in hetero-romantic and nuclear family relations). As she witnesses the everyday intricacies of colonialism, she becomes acutely aware of the urgent work that needs to be done by settlers to see themselves in reciprocal rather than in subjugating or appropriating relations and commits to the ongoing labour of de-colonizing in her kin relations. Her story reminds us that these histories—hers and perhaps, yours—need to be surfaced as part of coming to understand Indigenous / non-Indigenous relationships. For non-indigenous people, this means coming to know ourselves, and thus to know ourselves differently, in relationship to Indigenous people. 


\section{The Pervasive and Debilitating Effects of Everyday Gendered Racism}

The third and final set of stories explore the pervasive and debilitating effects of everyday gendered racism and how Indigenous storytellers speak back to its imposition on them. In these stories, gendered racism takes on different forms: it dresses itself in another culture's sacred items, it dislocates, it questions identity and resistance, it says whatever it wants to say without apology but most of all it gazes, stares, watches, and wants an explanation. The storytellers remind us that they are aware of the settler gaze, of being "looked at" and seen as other. Interwoven in their accounts are gestures towards ways that gendered and sexual looking shape the colonizing gaze, marking it as simultaneously heteropatriarchal and settler-colonial. They challenge us to turn the gaze on ourselves, to ask questions about our own participation in colonial racism and its processes. They also turn away from settler gazes in recuperating and affirming ways by turning toward and telling their stories for Indigenous audiences, enunciating their gendered selves in ancestral languages (Anishnaabe-kwe) and testifying about colonialism's imposition of overlapping gender, sexual and racial violence onto them. Their stories create a space in which re/turning the colonial gaze can be understood as the first alternation towards a genuine understanding of decolonization.

The first story by Anishnaabe educator Tasha Smith, Things I Should Have Said, returns the gaze and forcefully rejects it for its inability to see who she is, for the everyday dehumanization she experiences-her film talks back to the systems and processes that produce systemic injustice in the first place: in her art, she asserts what she is for in the face of what she is against (https://vimeo.com/album/4877492; password "unsettling"). Smith's rage boils up through her words but she also reveals it 
through the use of visceral images such as a painting of a face with bleeding eyes and lips sewn shut, and another of a locked door, scratched and splattered with paint with a sign reading "private." These images evoke an embodied sense of gendered and sexual violence past and present; the viewer is provoked to question what atrocities took place behind that closed door. The door could also be understood as a representation of the Indigenous female body. Mishuanua Goeman (Seneca) explains, "Native women's bodies, as markers against territorial appropriation, Indigenous futurities and contestations of colonial politics, are a locus of gendered colonial meanings and a site of contest" $(2017,107)$. To represent herself as Anishnaabe-kwe-an Indigenous woman-Smith intersperses these images with serene visuals of a double rainbow after a storm, a lake at sunset, and unique beadwork on moccasins. One can imagine that Smith's story begins after a specific encounter, one that is tied to a string of similar exchanges. It is her response to the daily micro-aggressions she endures. She considers all the vitriol she could have flung back at the ignorant remarks and actions. But Smith also turns towards love, towards family, in revealing her veneration for her grandmother's unshed tears. As Leey'qsun scholar Rachel Flowers (2015) tells us, Indigenous women's' rage, not just their love, is a powerful political tool to disrupt the dominion of settler colonialism. Tasha returns the gaze of the settler audience stating, "as occupier of this land you have a responsibility to learn the history of the land in which you stand and the first people who are on it." Here we catch of glimpse of a landbased world-view; all relations begin on and return to the land; the land is fundamental for self and community. Tasha demands that settler viewers learn Indigenous 
perspectives on the living histories and legacies of colonialism, and on continuing resistance and resurgence, which cannot be separated from reclamation of the land.

"No" reverberates through Smith's story; "No" to positioning her people in the past; "No" to violence perpetuated against Indigenous women; and "No" to "cheap knock-offs" of her culture's sacred items "on the appropriator's body." Smith refuses to be defined by the heteropatriarchal settler gaze, she tells us, "I will never be what you think I should or look like you think I should or act as you think I should." Her story embodies what Flowers (2015) describes as an Indigenous politic of refusal-a refusal to be defined by the settler gaze and a challenge to settlers to turn the gaze on themselves, and work to dismantle systems implicated in Indigenous oppression. Flowers (2015) writes that Indigenous rage is a legitimate response to the everyday gendered racism of colonialism and can be the generative force needed to create new relationships grounded in anti-colonial feminist resistance and a shared vision of an alternative future. This new understanding of anger allows us to read Smith's rage as an invitation for settlers to "listen, learn, and act in relation to the colonial difference alongside assertions of Indigenous sovereignty and nationhood" $(2015,34)$.

Winter, Inuk artist Geronimo Inutiq's story, in three acts, in three languages, both tells and conceals in important ways his experience of complex Indigenous masculinity (https://vimeo.com/album/4877492; password "unsettling"). His telling of the suffering, pain, and displacement that Indigenous men experience gestures toward the disproportionate representation of Indigenous bodies in child welfare systems, in shelters, in prisons, on the streets-the ongoing, everyday reminder of economic racism, of colonialism's continuing devastating effects. Beginning with a sustained shot 
of a tattered Canadian flag, blowing in the wind against the backdrop of an impersonal glass office tower while a single Inuk voice shares a song, Inutiq moves through images of flowers, leaves and trees to urban streets and alleyways. Inutiq's own gaze and presence remains concealed in the story (he only shows up as a shadow holding a camera at the end). We do not view Winter either, only the anonymous passing of others on a crowded urban street. Pedestrians walk quickly by, with merely a passing glance. Perhaps Inutiq is asking viewers to move past the mere gaze and bear witness to Winter's story, an arguably different task. We are immersed in Winter's painful story of dislocation and continual abandonment and our hungry gaze is denied an easy place to land. Instead we join Inutiq in roaming the city streets, so that we can listen and bear witness to Winter's testimony of loss and survival.

Métis scholar Judy Iseke (2011) elucidates that when we bear witness to stories of colonial trauma, we are witness to the trauma of storytellers and witness to our responses. By excluding visual representations of both himself and Winter, Inutiq masterfully creates an empty, yet full urban space so that we can, in a sense, partially experience Winter's trauma ourselves. Inutiq punctuates the monstrosity of Winter's foster home experiences by repeating the phrase at the end of the film, "Winter went through 38 foster homes." The story provokes the question of how we can contend with the brutality of the forced and continuous relocation of Indigenous bodies, a reality that marked Winter's childhood. And how, despite all this, "Winter is praying for us." Inutiq's double-voiced story—a conversation between two Indigenous men-invites us to think critically about any single-axis analyses that erases the forms of intimate violence done to Indigenous bodies, both female- and male-coded; to wonder about Inutiq's own story 
and the survival stories of other Indigenous boys and men who embody non-hegemonic and complex masculinities; and to consider the recuperation/revivification of all those boys and men whose experiences of oppression, dislocation, and abuse have been rendered unintelligible by euro-western, heteronormative white supremist patriarchal logics/binary systems.

The final story, A Day in the Life, was created by student Nyame Outten-Joseph, "an Afro-native youth of Mohawk and Mi'kmaw heritage" (https://vimeo.com/album/4877492; password "unsettling"). He begins with a moment of confrontation while he chooses to sit, rather than stand for his school's playing of the Canadian anthem. He juxtaposes images of him as a smiling happy child in elementary school, in his regalia with images of him from high school, now unsmiling, sitting (cornered?) in a corner staring back at the camera. He closes in on an image of his eye, wide-open and startled, as he speaks of feeling interrogated by students and teachers, using a pencil drawing of a house on fire to refute others' insistence that "Canada is a great place that offers a safe haven." With this, he surfaces the pervasive racist ignorance that surrounds daily life in and outside school in Canada, exposing the constant confrontation by teachers, classmates and other white settlers who challenge his identifications and acts of resistance. Without stating it explicitly, Outten-Joseph exposes white settler gendered readings of his Indigenous/black masculine body as threat. Robert Innes and Kim Anderson (Métis) describe how the hegemonic masculinity that perpetuates white supremacist patriarchy has become so pervasive that "it is next to impossible for Indigenous men not to be exposed." $(2012,10)$.

At the end of his story, Outten-Joseph returns the gaze, once again on the 
viewer, asking us to look at the ways that we construct Indigenous people. Are we willing to examine our role in continuing everyday gendered racism? Or will we continue to deny the lived experience that he reveals in his story and, as Métis scholar Tracy Friedel contends, deny "the power relations on which privilege and inequality depend" $(2010,28)$ ? Outten-Joseph contests the popular construction of Canadian identity as tolerant and non-violent, stating that Canada is not a safe haven for him; and he want us to know how the daily interrogation and ignorance he endures "twists and turns" at his insides. Still he reaches out his hand even as he feels that it is "slapped away." Outten-Joseph extends an implicit invitation to the viewer who, if they accept, must re/turn to the self to begin the painful process of excavating the deep-rooted lessons of colonization. Only then will it be possible to transform our relationships, forge alliances across difference, and move away from the continuation of a single-story of Indigenous victimhood. By exploring his intersectional embodiment, Outten-Joseph is not only returning the colonial gaze wherein Indigenous brown/black male bodies come to represent a negative "counterpoint to the preferred hegemonic white heteropatriarchal masculinity" (10); he is also demanding that we turn the gaze on ourselves and the collective denial intrinsic in the dominant (white, masculinist) Canadian identity.

Outten-Joseph's and Smith's stories can evoke strong reactions in the professional development workshops, with participating viewers disclosing feelings of guilt and shame. The initial impulse may be to reject or deny shame; however, it may be beneficial to sit with it. Feminist scholar Elspeth Probyn (2004) asks us to consider in what contexts shame might function as a catalyzing force for change, "immensely productive politically and conceptually in advancing a project of everyday ethics" (329). 
She contends that settler shame is a vulnerable affect present, even if unacknowledged, in our post-colonial relations, and can shock us out of our habitus-our everyday lived notions of self, place and relations. Dian Million (Tanana Athabascan) (2009) also discusses shame's productive qualities, arguing that in exploring the racialized, gendered, and sexual nature of their colonization, Indigenous feminist writers such as Lee Maracle and Maria Campbell have "transformed the debilitating force of an old social control, shame, into a social change agent in their generation" $(2009,54)$. This is the work that Outten-Joseph's and Smith's stories undertake.

\section{Conclusion}

Indigenous storywork pushes us to consider what a feminist decolonizing framework might bring to intersectionality studies and how it might transform the concept of intersectionality itself. As we know, structuralist approaches to intersectionality (from inter meaning between or among groups) (Rice, 2018) typically view identities and differences as discrete or separate categories that are produced/reproduced in hierarchical and relatively stable structures; and poststructuralist ones generally seek to understand how people express agency by making their subjectivities in, with and against contradictory, shifting social discourses. Moving beyond both structuralist and post-structuralist positions, an intra-sectional framework (intra meaning inside or within) (Rice, 2018) that draws from processual ontologies such as Indigenous, Deluezian and/or new materialist ontologies (Rice, Harrison \& Friedman, 2019; Rice, 2018; Tallbear, 2017) invites us to rethink identities as indivisibly embodied and as emergent via shifting symbolic, structural and organic forces co-implicated in their corporealization. Further, a decolonized reframing of 
intersectionality recognizes the centrality of land to self and nation and urges us to revise the analytic in ways that account for land-based concepts of identity-for how Indigenous notions of selves are simultaneously embodied and embedded. As the storytellers here narrate, they come to know themselves through lineage and land-to root their Indigenous identities in family/nation and in pre- and post-contact territories of their kin. A feminist decolonial approach acknowledges these entanglements and further enunciates (against settler attempts at annihilation) Indigenous peoples' indissoluble relationalities with land as an integral site of self and nation-making.

Indigenous, feminist and postcolonial scholars (Amad 2013; Kaplan 1997) have complicated the return-of-the-gaze phenomena through analyzing the counterhegemonic poetics and practices of diverse thinkers who have dreamed, imagined, spoken, written and filmed their way out of formerly colonized and otherwise subjugated subject positions. Analyses of these subject-object and self-other relations have moved beyond simple reversal to consider more complex relays, exchanges, clashes, and confrontations where subjects and observers are seen as grappling with the other, often in "contexts of highly asymmetrical relations of power, such as colonialism, slavery, or their aftermaths" (Amad 2013, 64). The makers featured here likewise complicate the returning-of-the-gaze-hermeneutic, not only reversing the look but turning it on themselves, in some cases, as in Rice's story, interrogating their own positionality in relation to heteropatriarchal colonial histories and legacies. In others, as in Neepin's, Smith's, and Allan's videos, the storytellers satirize, confront, refuse and challenge ignorance and hubris that characterize the patriarchal colonial panoptic look. Other video makers turn toward the Indigenous collective, family, and self, bearing 
witness, as in Inituq's story, to shared colonial trauma and pan-indigenous identity, and in Robinson's, to strategies of surviving and thriving through and past genocidal colonial regimes. Outten-Joseph looks outward as he challenges viewers to undertake the work of conciliation. In looking to Indigenous peoples and past settler-colonial institutions, these makers do more than complicate the return-of-the-gaze dynamic. They actively contribute to Indigenous nation-culture renaissance and resurgence by, in Simpson's words, "significantly re-investing in our own ways of being: regenerating our political and intellectual traditions; articulating and living our legal systems; language learning; ceremonial and spiritual pursuits; creating and using our artistic and performance-based traditions" $(2011,18-19)$ including by recuperating gender and sexual systems grounded in fluidity and gender complementarity. Recognition and working through of the overlaps between feminist and Indigenous studies makes possible new perspectives on what is necessary for decolonizing institutions. It also opens up the possibility of new forms of activism based on intersectional alliances, such as alliances among feminist, two-spirit, racialized and Indigenous youth, rather than assuming alliances can only happen amongst certain homogenized groups of people—namely, women or Indigenous peoples.

Interrogating the complex relay of gazes operating in and through these films raises important questions about the possibility of an Indigenous feminist aesthetic. If Indigenous filmmakers contribute an embedded aesthetics and feminist filmmakers, to an embodied aesthetics, how might the video-makers participating in our projects contribute to an embodied and an embedded aesthetics? In the collection of videos analyzed here, Neepin, Robinson, Rice, Smith, Allan, Initiq and Outten-Joseph each 
speak from their intersectional embodiments-as Anishinaabe, Mohawk, Mi'kmaq, AfroNative, Inuit-French-English, Anishinaabe-kwe, Two-Spirit, man, woman, genderqueer, queer, and/or white settler-as they situate themselves in relationship to community and kin, to nation and land. Alongside aesthetics, analyzing the dynamics of gazing raises important considerations about audience reception. When presenting and analyzing these stories, we often address the viewer's thinking heart and feeling mind. This means that we ask audiences to open ourselves to, in Million's words, a "felt analysis...that creates a context for a more complex 'telling'” $(2009,54)$, one that illuminates deeper meanings of Indigenous/ non-indigenous relations, the entangled gazes and the layered systems of oppression—of heteronormativity, white supremacy, and patriarchy-that we must confront to decolonize institutions and to achieve Indigenous sovereignty. We extend Million's words to include how you, as readers, listeners and viewers, receive the stories presented in this article. Beyond reminding us of our responsibility to interrogate our affects and positionalities in relationship to the stories told, we heed Million's message as a call to action: how will you come to know yourself and begin the work of acting differently now that you've witnessed these stories?

\section{References}

Amad, Paula. 2013. "Visual Riposte: Looking Back at the Return of the Gaze as

Postcolonial Theory's Gift to Film Studies." Cinema journal 52 (3): 49-74. Anderson, Kim. 2016. A Recognition of Being: Reconstructing Native Womanhood. Toronto: Canadian Scholars' Press. 
Archibald, Jo-ann. 2008. Indigenous Storywork: Educating the Heart, Mind, Body, and Spirit. Vancouver: University of British Columbia Press.

Arvin, Maile, Eve Tuck, and Angie Morrill. 2013. "Decolonizing Feminism: Challenging Connections between Settler Colonialism and Heteropatriarchy." Feminist Formations 25 (1): 8-34.

Carter, Jill, Karyn Recollet, and Dylan Robinson. 2017. "Interventions into the Maw of Old World Hunger: Frog Monsters, Kinstellatory Maps, and Radical Relationalities in a Project of Reworlding." In Vol. 7 of Canadian Performance Histories and Historiographies: New Essays on Canadian Theatre, edited by Heather Davis-Fisch, 205-231. Toronto: Playwrights Canada Press.

Dion, Susan D. 2009. Braiding histories: Learning from Aboriginal Peoples' Experiences and Perspectives. Vancouver, BC: UBC Press.

Dion, Susan D., Krista Johnston, and Carla Rice. 2010. Decolonizing Our Schools: Aboriginal Education in the Toronto District School Board. (Report). Toronto, ON: Toronto District School Board.

Driskill, Qwo-Li, Daniel Heath Justice, Deborah A. Miranda, and Lisa Tatonetti. 2011. Sovereign Erotics: A Collection of Two-Spirit Literature. Tucson, AZ: University of Arizona Press.

Flowers, Rachel. 2015. "Refusal to Forgive: Indigenous Women's Love and Rage." Decolonization: Indigeneity, Education \& Society 4 (2): 32-49.

Francis, Daniel. 2012. The Imaginary Indian: The Image of the Indian in Canadian Culture. Vancouver: Arsenal Pulp Press. 
Friedel, Tracy. 2010. "The More Things Change, the More They Stay the Same: The Challenge of Identity for Native Students in Canada." Cultural and Pedagogical Inquiry 2 (1): 22-45.

Goeman, Mishuana, 2017. "Ongoing Storms and Struggles: Gendered Violence and Resource Exploitation." In Critically Sovereign: Indigenous Gender, Sexuality, and Feminist Studies, edited by Joanne Barker, (99-126). Durham and London: Duke University Press.

Hanson, Helen, and Catherine O'Rawe. 2010. The Femme Fatale: Images, Histories, Contexts. Houndmills, England: Macmillan.

Hunt, Sarah. 2018. "Embodying Self-Determination: Beyond the Gender Binary." In Determinants of Indigenous Peoples' Health, edited by Margo Greenwood, Sarah de Leeuw, and Nicole Marie Lindsay, 22-39. Toronto: CSP Books.

Innes, Robert Alexander, and Kim Anderson. 2012. "Who's Walking with Our Brothers?" In Indigenous Men and Masculinities: Legacies, Identities, Regeneration, edited by Robert Alexander Innes and Kim Anderson, (pp. 3-20). Manitoba: University of Manitoba Press.

Iseke, Judy M. 2011. "Indigenous Digital Storytelling in Video: Witnessing with Alma Desjarlais." Equity \& Excellence in Education 44(3): 311-329.

Kaplan, E. Ann. 2012. Looking for the Other: Feminism, Film and the Imperial Gaze. New York: Routledge.

Knopf, Kerstin. 2010. “' 'Sharing Our Stories with All Canadians': Decolonizing Aboriginal Media and Aboriginal Media Politics in Canada." American Indian Culture and Research Journal 34 (1): 89-120. 
Kovach, Margaret. 2009. Indigenous Methodologies: Characteristics, Conversations, and Contexts. Toronto: UT Press.

Lind, Emily, Crystal Kotow, Carla Rice, Jen Rinaldi, Andrea LaMarre, May Friedman, and Tracy Tidgwell. 2017. "Reconceptualizing Temporality in and through Multimedia Storytelling: Making Time with Through Thick and Thin." Fat Studies 7 (2): 181-192.

MacKenzie, Scott, and Anna Westerståhl Stenport. 2016. "Arnait Video Productions: Inuit Women's Collective Filmmaking, Coalition Politics, and a Globalized Artic." Camera Obscura: Feminism, Culture, and Media Studies 31 (93): 153-163.

Million, Dian. 2009. "Felt Theory: An Indigenous Feminist Approach to Affect and History." Wicazo Sa Review 24 (2): 53-76.

Mulvey, Laura. 1975. "Visual Pleasure and Narrative Cinema." Screen 16 (3): 6-18

Olsen, Torjer A. 2017. "Gender and/in Indigenous Methodologies: On Trouble and Harmony in Indigenous Studies." Ethnicities 17 (4): 509-525.

Probyn, Elspeth. 2004. "Everyday Shame." Cultural Studies 18 (2-3): 328-349. Rinaldi, Jen Carla Rice, Andrea LaMarre, Karleen Pendleton Jiménez, Elisabeth Harrison, May Friedman, Deborah McPhail, Margaret Robinson, and Tracy Tidgwell. 2016. “Through Thick and Thin: Storying Queer Women's Experiences of Taking Up and Resisting Idealized Body Images and Expected Body Management Practices," Psychology of Sexualities Review 7 (2): 63-77.

Rinaldi, Jen, Carla Rice, Andrea LaMarre, Deborah McPhail, and Elisabeth Harrison. 2017. Fatness \& Failing Citizenship. Somatechnics 7 (2): 218-233. 
Rice, Carla, Karleen Pendleton Jiménez, Elisabeth Harrison, Margaret Robinson, Jen Rinaldi, Andrea LaMarre and Jill Andrew. Forthcoming. "Bodies at the Intersection: Reconfiguring Intersectionality through Queer Women's Creative Accounts of their Complex Embodiments," Signs: A Journal of Women in Culture and Society.

Rice, Carla and Ingrid Mündel. 2019. "Multimedia Storytelling Methodology: Notes on Access and Inclusion in Neoliberal Times," Canadian Journal of Disability Studies, 8 (2): 118-146.

Rice, Carla and Ingrid Mündel. 2018. "Storymaking as Methodology: Disrupting Dominant Stories through Multimedia Storytelling." Canadian Review of Sociology 55 (2): 211-231.

Rice, Carla, Andrea LaMarre, Nadine Changfoot and Patty Douglas. 2018. "Making Spaces: Multimedia Storytelling as Reflexive, Creative Praxis." Qualitative Research in Psychology. DOI: 10.1080/14780887.2018.1442694

Rice, Carla, Eliza Chandler, Kirsty Liddiard, Jen Rinaldi and Elisabeth Harrison. 2018. “The Pedagogical Possibilities for Unruly Bodies." Gender \& Education 30 (5): 663-682.

Rice, Carla, Eliza Chandler, Elisabeth Harrison, Manuela Ferrari, and Kirsty Liddiard. 2015. "Project Re•Vision: Disability at the Edges of Representation. Disability \& Society 30 (4): 513-527

Romero, Channette. 2010. "The Politics of the Camera: Visual Storytelling and Sovereignty in Victor Masayesva's Itam Hakim, Hopiit." Studies in American Indian Literatures 22 (1): 49-75. 
Salazar, Juan Francisco, and Amalia Córdova. 2008. "Imperfect Media and the Poetics of Indigenous Video in Latin America." In Global Indigenous Media: Cultures, Poetics, and Politics, edited by Pamela Wilson and Michelle Stewart, (pp. 39-58). Durham: Duke University Press.

Simpson, Leanne Betasamosake. 2011. Dancing on Our Turtle's Back: Stories of Nishnaabeg Re-creation, Resurgence and a New Emergence. Winnipeg: Arbeiter Ring.

Simpson, Leanne Betasamosake. 2017. As We Have Always Done: Indigenous Freedom through Radical Resistance. Minneapolis: U of Minnesota Press. Sneider, Leah. 2012. "Complementary Relationships: A Review of Indigenous Gender Studies." In Indigenous Men and Masculinities: Legacies, Identities, Regeneration, edited by Robert Alexander Innes and Kim Anderson, (pp 62-79). Winnipeg: University of Manitoba Press.

St. Denis, Verna. 2013. "Feminism is for Everybody." In Gender and Women's Studies: Critical Terrain, edited by Margaret Hobbs and Carla Rice, 16-28. Toronto: Canadian Scholars' Press.

Suzack, Cheryl, Shari Huhndorf, Jeanne Perreault, and Jean Barman, eds. 2010. Indigenous Women and Feminism: Politics, Activism, Culture. Vancouver: UBC Press.

TallBear, Kim. 2015. "An Indigenous Reflection on Working Beyond the Human/Not Human." GLQ: A Journal of Lesbian and Gay Studies. 21 (2): 230-235. 